\title{
Transposing an active fault database into a seismic hazard fault model for nuclear facilities - Part 1: Building a database of potentially active faults (BDFA) for metropolitan France
}

\author{
Hervé Jomard $^{1}$, Edward Marc Cushing ${ }^{1}$, Luigi Palumbo ${ }^{2}$, Stéphane Baize ${ }^{1}$, Claire David ${ }^{2}$, and Thomas Chartier ${ }^{1, a}$ \\ ${ }^{1}$ IRSN, Institute of Radiological protection and Nuclear Safety, BP17, 92262 Fontenay-aux-roses CEDEX, France \\ ${ }^{2}$ Neodyme, Joue les Tours, 37300, France \\ anow at: Département de Géosciences, Ecole Normale Supérieure, Paris, 75005, France
}

Correspondence to: Hervé Jomard (herve.jomard@irsn.fr)

Received: 9 March 2017 - Discussion started: 14 March 2017

Accepted: 19 July 2017 - Published: 20 September 2017

\begin{abstract}
The French Institute for Radiation Protection and Nuclear Safety (IRSN), with the support of the Ministry of Environment, compiled a database (BDFA) to define and characterize known potentially active faults of metropolitan France. The general structure of BDFA is presented in this paper. BDFA reports to date 136 faults and represents a first step toward the implementation of seismic source models that would be used for both deterministic and probabilistic seismic hazard calculations. A robustness index was introduced, highlighting that less than $15 \%$ of the database is controlled by reasonably complete data sets. An example of transposing BDFA into a fault source model for PSHA (probabilistic seismic hazard analysis) calculation is presented for the Upper Rhine Graben (eastern France) and exploited in the companion paper (Chartier et al., 2017, hereafter Part 2) in order to illustrate ongoing challenges for probabilistic faultbased seismic hazard calculations.
\end{abstract}

\section{Introduction}

The practice acquired in nuclear regulation over the last decade as well as the feedback arisen from recent earthquake consequences on nuclear power plants (e.g. KashiwazakiKariwa in 2007, Fukushima and North Anna in 2011) have challenged the expertise of the IRSN (French Institute for Radiation Protection and Nuclear Safety). Hence, IRSN's research related to the geological aspects of seismic hazard analysis (SHA) has been focused on three principal axes: (1) updating national seismotectonic zoning pattern (Baize et al., 2013), (2) performing and publishing collaborative studies on specific French active faults (see Cushing et al., 2008; Baize et al., 2011; García-Moreno et al., 2015; De La Taille et al., 2015) and (3) implementing the BDFA (from the French term Base de Données des Failles Actives which means active faults database), a database concerning the potentially active faults of metropolitan France. These issues directly follow key aspects reported in the international recommendations for SHA in dedicated site evaluation guides (see IAEA, 2010) in which matters linked with both seismic motions and surface faulting are addressed and in the requirements of the the French deterministic fundamental safety rules (RFS 2001-01, ASN, 2001) for the determination of ground motion at sites.

The above-mentioned third axis started in 2009 and consists of the ongoing BDFA project (Palumbo et al., 2013). It represents a first step to supporting SHA calculation, which needs a collection of geological information in order to characterize seismic sources. This new database compiles available data on faults with post-Late Miocene activity evidence in metropolitan France, including geometrical properties, kinematics, slip rates, etc. All this information is made available as a fault map and in related tables for further application. Currently, the project focuses on faults that are longer than $10 \mathrm{~km}$ (roughly capable of producing $M \geq 6$ events according to Wells and Coppersmith, 1994) and cross a $50 \mathrm{~km}$ circular area with their radius centred on French nuclear facilities (Fig. 1). Future implementations of BDFA should address larger areas of investigation, i.e. at country scale. 
BDFA aims to represent a first step towards the constitution of a seismic sources catalogue that can be later used in SHA as well as in PFDHA (probabilistic fault displacement hazard analyses) calculations. An outlook of BDFA in the Upper Rhine Graben and its transcription into a source model for PSHA calculation is presented in Sect. 4 of this paper.

\section{Rationale behind BDFA}

Despite its distance to active plate boundaries and relatively low to moderate seismotectonic activity (intraplate domain), both significant earthquakes (e.g. historical catalogue, SISFRANCE, 2016) and surface faulting (e.g. Sébrier et al., 1997; Chardon et al., 2005) have occurred in metropolitan France during historical and pre-historical times.

The starting point for building the BDFA relied on previous research, namely (1) the seismotectonic map released by Grellet et al. (1993) and the active fault database of southeastern France (Terrier, 2004), (2) the IRSN catalogue of faulting evidence affecting Quaternary deposits (Baize et al., 2002), and (3) the French catalogue of neotectonic evidence (available online at www.neopal.net). This early work was based upon both a catalogue of published (scientific articles, $\mathrm{PhD}$ thesis, etc.) and unpublished reports (technical reports, master thesis, etc.) as well as an important interpretation phase performed by the authors themselves.

BDFA aims to reflect the available data sets as much as possible, either for the establishment of fault mapping or for the description of the fault activity. Because various opinions may have been proposed by different authors at different times and at different scales, we compiled their interpretations/data in a specific form for each fault complementing the BDFA traces and tables. Our own choices of fault parameters and associated uncertainties are therefore tracked and referenced to the aforementioned form. These forms and the neotectonic and structural syntheses compiled at regional scales (i.e. Alps, Britany, Jura Mountains, etc.) are written in French and are available upon request.

Among the parameters compiled in the database, we focused on the two following critical points.

\subsection{Defining the surface fault trace}

The main cartographic reference for the BDFA is that of Grellet et al. (1993), who, following Fourniguet (1978), first attempted to synthesize neotectonic and active faults across France at the 1:1000000 scale. This fault mapping went through many simplifications and a rough cartographic representation, so that it cannot be operated at a more precise scale. Our first objective was then to improve this mapping through the analysis of broad literature including geological and thematic maps at different scales (down to $1: 50000$ geological maps), digital elevation models (DEMs), aerial pho- tographs when available, and specific publications containing maps at various scales. BDFA is developed under a GIS structure in which the basic unit is the fault segment, coupled with a relevance index describing the status of knowledge concerning its cartographic trace (reliable, uncertain, hidden, and suspect). Faults may be defined from a single segment or a set of segments forming a discontinuous trace at the surface. The fault segments traces are paired with explicit tables reporting the data gathered in the literature and tracing the consulted sources as much as possible.

\subsection{Discriminating whether a fault is considered active or not}

This task represents a key point of the database which is, however, not straightforward to determine, because of both scientific and regulatory issues.

From a scientific point of view, when no sign of current activity is recorded along a fault (from seismicity and geodesy), which is often the case in intraplate domains, determining whether a fault is active or not is based upon the age of the youngest observed deformation, with particular attention to multiple movements occurring over the last thousands to hundreds of thousands of years.

From a regulatory point of view, national and international definitions of when a fault should be considered active may differ when it comes to deciding on the temporal limits that should be taken into account. Concerning the determination of ground motion at sites, the French Nuclear Safety Authority rules (ASN, 2001) recommend, for example, that the hazard related to an active fault should be taken into account when defining the ground motion related to a potential event whose return period is of the order of a few tens of thousands of years. Concerning the fault displacement hazard, the international nuclear safety guideline (IAEA, 2010) indicates that for intraplate domains, fault capability (i.e. capacity of a fault to rupture the surface during an earthquake) should be assessed by collecting geological information covering the Plio-Quaternary period (the temporal threshold to account for should then be 5.3 Myr). This time span is significantly larger than the one proposed by the US Nuclear Regulatory Commission (U.S. NRC, 2017) which advises setting this limit to $35 \mathrm{kyr}$ for faults that ruptured once at or near the surface or $0.5 \mathrm{Myr}$ for faults highlighting recurring earthquakes.

At the metropolitan France scale, the orientation of the tectonic stress field has not experienced dramatic changes since the end of Miocene, with the persistence of the convergence between Africa and Eurasia. In parallel, the age of PlioQuaternary sediments that may attest for deformation along faults are often absent or poorly constrained. In this context, we regarded the re-activation of past structures as possible and build the BDFA as a potentially active fault database, thus including the late Miocene to Quaternary structures as considered in a previous compilation by Baize et al. (2013) (Fig. 1). 


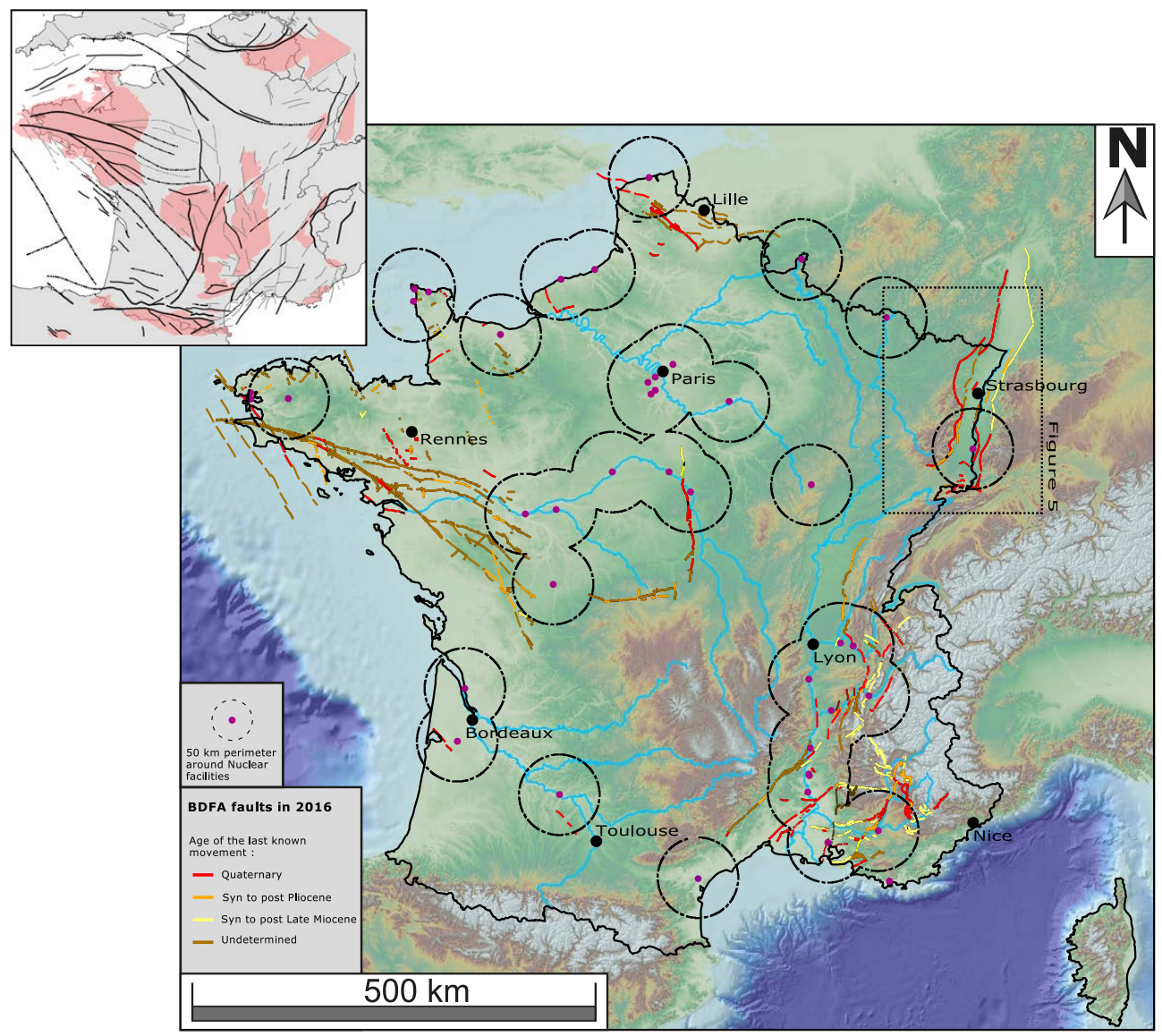

Figure 1. Map of BDFA (Google Earth kml file provided in the Supplement) at the scale of metropolitan France. Faults coloured by the age of the last known movements. Black circles represent a $50 \mathrm{~km}$ perimeter around each nuclear facility. The black dashed rectangle represents the geographical imprint of Fig. 5. In the top left is a simplified structural sketch of France (modified from Baize et al., 2013): crystalline basement outcrops are defined in light red, major basement faults in black, and minor faults in grey.

\section{The database structure and statistics}

The database structure (see the Supplement) was inspired by other databases developed in the world, such as the ones from the USA (QFAULT; Haller et al., 2004), New Zealand (NZAFD; Langridge et al., 2016), Japan (Active Fault Database of Japan; AIST, 2016), Italy (ITHACA; Michetti et al., 2000) and Iberia (QAFI; García-Mayordomo et al., 2012). The proposed map for metropolitan France is associated with a relational database describing the state of knowledge for each fault segment. This database is composed of several thematic tables (designed in Microsoft Excel spreadsheets) linked together with an identification key.

The identification key for each fault described in BDFA (ID_Fault - IDF) corresponds to the one referenced in the French Geological survey (BRGM) fault database related to the $1: 1000000$ geological map. A new identification key gives a unique reference to each fault segment (ID_UNIQUE - UID). These two identification keys allow the following tables to be linked together:
- The main table contains all gathered fault parameters with associated uncertainties when available (i.e. map characteristics, geometry, neotectonics, ages and kinematics, calculation of a robustness index, editing notes and release date).

- The index-ref and reference tables list the publications used to characterize the faults.

- The index-evidence table includes all neotectonic evidence reported in the NEOPAL and IRSN databases (respectively NEOPAL, 2009 and Baize et al., 2002).

- The index-seismic table reports the largest earthquakes, essentially events described in the historical archives (SISFRANCE) for which magnitude values are proposed by Baumont and Scotti (2011).

All fields are described in the BDFA table enclosed in the Supplement. Most of them are manually implemented, but we took advantage of GIS capabilities to implement cartographic parameters such as length, azimuth, tips coordinates. 
When a field cannot be filled because of a lack of data, a numerical code of 99 is attributed for numerical fields and an UnDef code is attributed for text fields.

\subsection{Fault traces and segmentation}

Fault segmentation and location are key parameters in seismic hazard assessment (Wesnousky, 1986; Field et al., 2015; Biasi and Wesnousky, 2016). While building up the BDFA, we mapped fault traces and associated segmentations directly as they were defined in the literature. Where several references were available for a single fault or fault segment, we decided to report the traces proposed from the most recent or reliable references. These principles have largely been applied for faults in eastern, northern, and southern France, because most of them have been studied for many years. However, the age of some publications led us to propose an alternative mapping in light of more recent cartographic documents (see the second point below).

In parallel, few active or potentially active faults have been studied in detail in central and north-eastern France. It may also happen, in particular for long faults (e.g. the south Armorican shear zone is longer than $500 \mathrm{~km}$ ), that only one or a few segments of a fault have been studied because of the occurrence of a particular local seismic crisis or the exposure of local neotectonic evidence. Consequently, precise mappings are often missing or not reliable due to coarse drawings. In this context, we complemented the available fault traces with a new mapping, including fault segmentation based on the following:

- As defined earlier, the basic unit filled in the database is the fault segment (UID), grouped into a fault (IDF), forming a discontinuous trace at the surface.

- In order to propose a surficial trace of the fault segments, we relied on the available map documents with a cartographic scaled approach. Priority was given to large-scale geological maps from the French geological survey $(1: 50000)$ and then, if not available, to lowerscale maps $(1: 250000,1: 1000000)$. As a last resort, DEMs and derived slope maps, as well as air photos, were analysed to propose fault segment traces based on their topographic signature. Finally, each proposed fault segment trace goes along with a reliability index (TRA: reliable, uncertain, hidden, or suspect). This reliability index was also adopted to qualify all faults segments of the database.

- Fault segments were archived into four typologies (major: M, parallel: P, oblique: $\mathrm{OB}$ and orthogonal: $\mathrm{OX}$ ). This term was introduced to differentiate what is considered to be the main fault trace (major) from satellite or conjugate systems. This is especially useful for inherited faults in hard rocks (e.g. Armorican shear zones) for which geologists have mapped all brittle structures

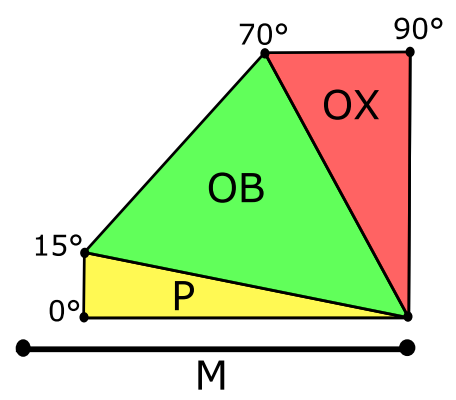

OX : Orthogonal to $M$

$O B$ : Oblique to $M$

$P$ : Parallel to $M$

$M$ : Major fault segment

Figure 2. Segmentation typologies (TYP) used to define the identity code of each segment (UID).

and where it is not possible to reject the potentiality of faulting due to the activation of the main structure. This distinction accounts for the relative strike of the subordinate segments with respect to the major fault trace $(\mathrm{M})$ : between 0 and $15^{\circ}=\mathrm{P}$, between 16 and $70^{\circ}=\mathrm{OB}$ and between 71 and $90^{\circ}=\mathrm{OX}$ (Fig. 2).

- The unique identification number (UID) of each fault segment is obtained by concatenating IDF, the segment typology (M, P, OB, OX) and the number of the segment (SNB). As an example (Table 1), the second major segment of the Vuache fault $(\mathrm{IDF}=5317)$ will be quoted 5317_2_M.

In any case, whether the retained geometries derive from publications or maps, fault segments are always defined on the basis of static geologic criteria or at least long-term morphological evidence of deformations. This is mainly due to the fact that, in metropolitan France, dynamic criteria (surface ruptures, fault source models, etc.) cannot be derived from the analyses of major earthquakes, the last surfacerupturing event probably being the Lambesc earthquake in 1909 (Chardon et al., 2005).

\subsection{Age of deformations and slip rates}

The age of the youngest deformed geological horizon will condition whether the causative fault/fault segment is considered in hazard calculations or not (French RFS 2001-01; IAEA, 2010; U.S. NRC, 2017). A second time, once a fault or a fault segment is considered, the associated slip rate will be the most influencing parameter in quantifying its seismogenic activity.

Consequently, we designed the database to provide the necessary parameters to (1) assess the age of the last movement along a fault or fault segment, and (2) calculate slip rates or understand how they were derived. Concerning the age of the last movement, we defined the following parameters to be filled in the database for each fault segment:

- The DCHR (deformed chronostratigraphic unit) field indicates the local terminology of the most recent chronostratigraphic unit involved in faulting. These may 
Table 1. BDFA parameters concerning the 5317_2_M segment of the Vuache fault. Data derived from Baize et al. (2011).

\begin{tabular}{lll}
\hline BDFA fields & Parameters in BDFA & Comments \\
\hline UID & 5317_2_M & Vuache fault Balme de Sillingy segment \\
DCHR & End of Riss & Deformed Rissian deposits, observed in a quarry \\
DCHRT & 99 & Top of deposits are lacking \\
DCHRB & $139 \mathrm{kyr}$ & Result from OSL dating is $139 \pm 16 \mathrm{kyr}$ \\
DM & Radiometric & OSL dates \\
NWEU & Eemian-Saalian & - \\
UCHR & UnDef & No overlying sediments \\
NEOF & $2000 \mathrm{~m}$ & Morphological shift of the Mandallaz anticline \\
OST & $13.6-7.2 \mathrm{Myr}$ & Base of Serravalian - top of Tortonian \\
AR & Miocene & Deformation in Jura Mountains starts between base of Serravalian and top of Tortonian \\
Slip rate & $0.15-0.28 \mathrm{~mm} \mathrm{yr}^{-1}$ & Horizontal slip rate \\
\hline
\end{tabular}

refer to epochs (e.g. Pliocene, Quaternary) or to more precise stages (e.g. Riss, Würm) due to the fact that Plio-Quaternary deposits are often poorly dated, Depending on the age defined in DCHR, a generic field called neotectonic age (NA) is provided in addition and used for mapping. Four predefined terms were adopted to fill the NA field: Quaternary, Pliocene (i.e. syn- to post-Pliocene), Miocene (i.e. syn to post-Late Miocene), and Undetermined. As a consequence, it may happen, because of missing sediments or datings along specific fault segments, that different ages are attributed to segments of a single fault. In this case, it is up to the user to decide whether the considered fault is active or not.

- DCHRT and DCHRB (DCHR top and base, in years) inform the numerical age of the top and the base of the youngest unit (DCHR) involved in the faulting. It may happen that one, both, or none of these ages are available.

- DM (dating method) refers to the dating method used to establish DCHRT and DCHRB. We rely on three predefined terms: (1) radiometric, when numerical ages are available; (2) relative, when ages of movement can be constrained by stratigraphic or biostratigraphic information and (3) indirect when only facies correlations are available at regional scales.

- NWEU (north-west European chronostratigraphic stages) - because the terminology of Quaternary glaciations used over time in the French bibliography often refers to Alpine regional stages, we introduced a field referring to their corresponding north-western European stages.

- UCHR (undeformed CHRonostratigraphic unit) indicates the local terminology of the oldest chronostratigraphic units not involved in the faulting. As mentioned previously, DCHR may cover a wide variety of terms.
Concerning slip rates, we were rarely able to extract from the consulted references direct information concerning fault slip rates. Published slip rate values were controlled before integration into the database, when chronological and/or stratigraphical issues arose because of either ambiguous, vague, or even inconsistent information. When reliable constraints in terms of chronology and amount of slip can be extracted from the consulted references (scientific papers, maps, etc.), then we propose slip rates based on these observations. The following parameters are filled in the database:

- NEOF (neotectonic offset). It informs the minimum and maximum offset values of the marker used to estimate slip rates and associated uncertainties. In general, it corresponds to the amount of slip registered by the youngest available dated and faulted marker.

- OST (offset span time, in years). It reports the time span used to calculate slip rates. It could be either a single value or a bracket depending on the presence or absence of dated deformation markers.

- AR (age used for rate). It mentions the name of the chronostratigraphic units constraining OST. It may happen that OST does not correspond to DCHR because the amount of slip (i.e. NEOF) in the youngest affected sediments can not be quantified. In this case, longer-term slip rates may be derived from older stratigraphic/morphologic markers.

Slip rate ranges are finally calculated by dividing NEOF with OST. When sufficient data are available, they may be decomposed in vertical slip rate (VSR) and/or horizontal slip rate (HSR).

In Fig. 3, we illustrate a theoretical case in which we reported the different fields informed in the database. This corresponds to an ideal case in which stratigraphic markers with absolute ages are available within the youngest deformed unit, which will allow for the recovery of a range of slip rates related to the most recent deformed horizon. 


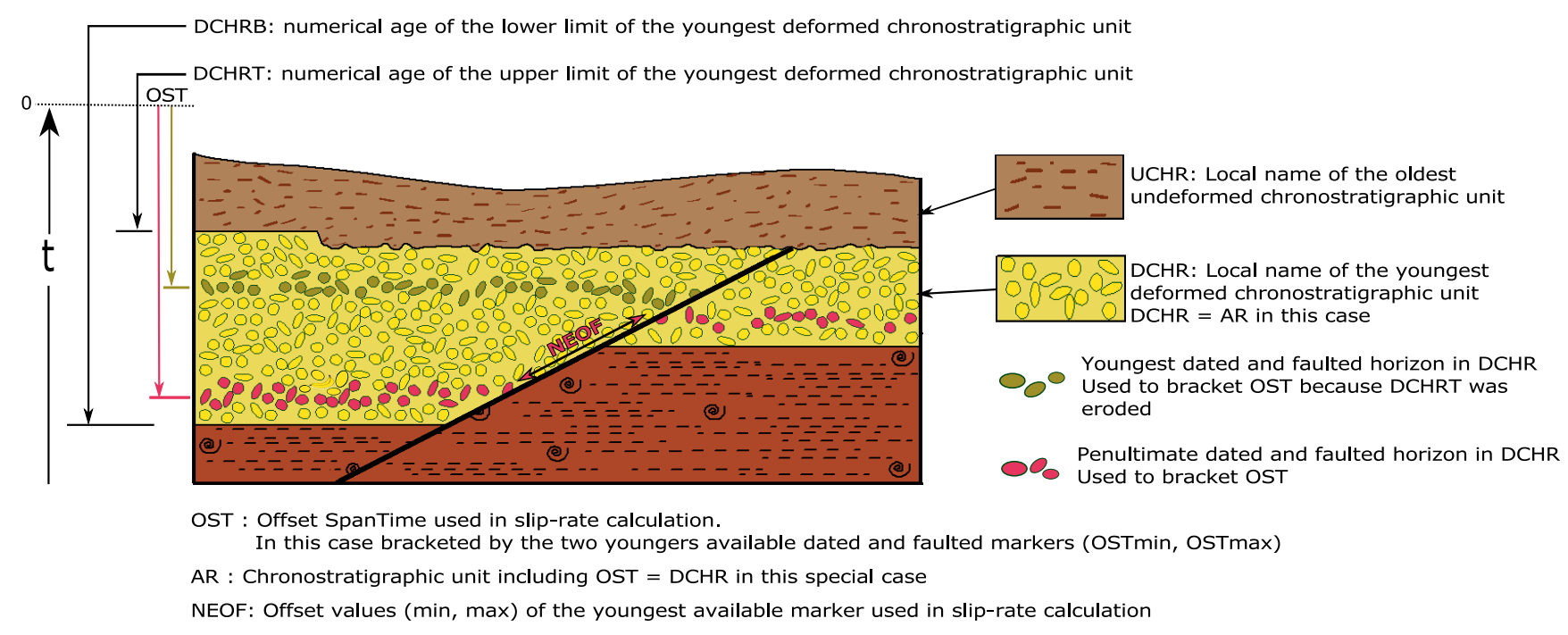

$\longrightarrow$ Slip-rate would finally be bracketed between $\left\langle\begin{array}{l}\text { NEOF }(\min ) / \text { OST }(\max )=\text { slip-rate min } \\ \text { NEOF }(\max ) / \text { OST }(\min )=\text { slip-rate max }\end{array}\right.$

Figure 3. Conceptual example illustrating the different chronological terms used in BDFA to determine the age of deformations and slip rates.

A real example illustrating the use of long-term slip rates because of missing quantified tectonic offsets in the most recent formations is given for the Vuache fault and derived from the publication of Baize et al. (2011). The parameters introduced in the database for the 5317_2_M segment are reported in Table 1. Along this fault segment, faulted Quaternary deposits were observed in a quarry and dated at the end of Riss $(\approx 139 \mathrm{kyr}$ ) through OSL (optically stimulated luminescence) techniques. Authors were unfortunately not able to quantify the deformation in these sediments. In order to define a long-term fault slip rate, they focused on a wellmarked morphological shift of $2 \mathrm{~km}$ of the Mandallaz anticline, related to the formation of the Jura Mountains, which started during the Miocene (between the onset of the Serravallian and the end of the Tortonian). Assuming a constant deformation rate since the Miocene, they estimated a 0.15 to $0.28 \mathrm{~mm} \mathrm{yr}^{-1}$ slip rate that is reported in the database.

\subsection{Robustness index}

The current version of the database includes 136 faults with a total of 581 fault segments. Among these 581 segments, 118 are reported as active during the Quaternary. We provide a robustness index (RI), estimated for each segment. This index aims to provide a ranking of the fault population in terms of reliability of their potential activity. RI (Eq. 1) follows the empirical expression modified from Baize et al. (2012):

$\mathrm{IR}=(\mathrm{TI}+0.1) \cdot(\mathrm{TI}+\mathrm{IAN}+\mathrm{GI}+3 \mathrm{HIST}+4 \mathrm{INST}+2 \mathrm{GDR})$,

where TI is the trace index (structural knowledge). It may be valued at 0 or 1 , according to unknown or well-known tectonic structures, respectively (see field TRA in the BDFA tables). IAN is the age index (time of last recognized displacement). Having been derived from the NA field, it may be valued at 1, 2, or 3 for the Miocene, Pliocene, and Quaternary, respectively, and at 0 for undefined/presumably postPaleogene. GI is the geomorphological index (morphological expression of the fault). It may be valued at 0 or 1 depending on negligible or prominent surficial expression, respectively. HIST questions whether historical seismicity could be associated with the segment fault trace. It may be valued at 0 or 1 . The value 1 is adopted when a significant historical earthquake (epicentral intensity $\geq \mathrm{V}$, according to SISFRANCE, which for this intensity level may be considered complete since the middle of the 19th century according to Bonnet et al., 2014) occurred within $5 \mathrm{~km}$ from the fault trace. INST questions whether instrumental seismicity could be associated with the segment fault trace. It may be valued at 0 or 1 . The value 1 is adopted when significant instrumental activity (either significant earthquakes with $M_{1} \geq 4$ or swarms/alignments of low magnitude events) occurred within $5 \mathrm{~km}$ from the fault trace. GDR is geodetical data indicating displacement between the two sides of the fault. It may be valued at 0 in the case of lacking data or 1 if the fault is actually experiencing active deformations.

This index is subjective by nature. It gives a higher weight to dynamic criteria like seismicity, because we consider that it is the most relevant criterion to prove seismotectonic activity. The total population of the database was classified within equally separated RI classes (Fig. 4). It highlights that a relatively small part of BDFA fault segments are reliably poten- 


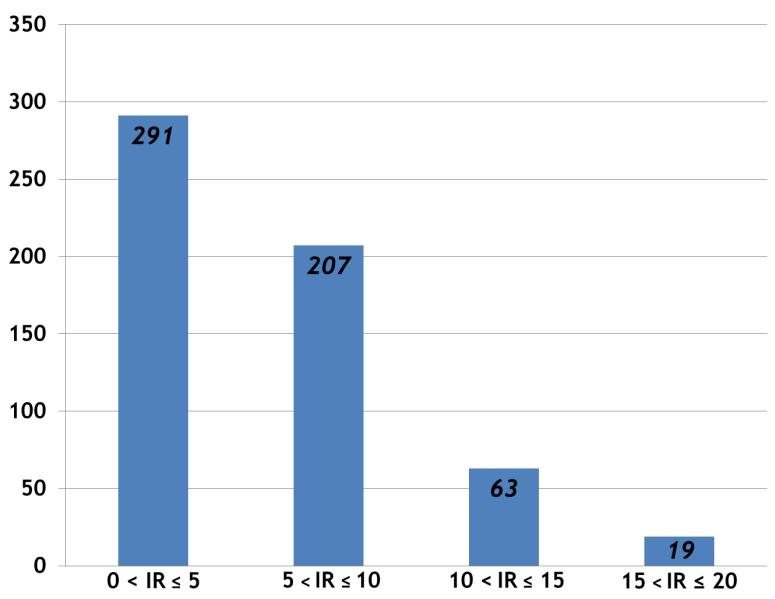

Figure 4. Robustness index (RI) distribution for all fault segments described in BDFA.

tially active ( 82 segments with an $\mathrm{RI}>10$, corresponding to 42 faults over 136 or $\approx 15 \%$ of the database) and may then help pointing out the need for future data acquisitions.

\section{Transposing BDFA into a fault seismic source model for SHA, an exercise in eastern France}

The southern part of the Upper Rhine Graben (URG) straddles the border between France and Germany from northern Switzerland to Mainz in western Germany. It presents significant seismic activity for an intraplate area with, for instance, a magnitude 4 or greater earthquake shaking the area every $\approx 10$ years (Bonjer et al., 1984; Barth et al., 2015). In 1356, a magnitude $\approx 6.5$ struck the city of Basel in its southernmost part (Lambert et al., 2005). This event is the largest regional earthquake that is listed in the Swiss, German, and French archives. Macroseismic intensities, based on reported damages, reached VIII-IX in the epicentral area according to the French macroseismic catalogue (SISFRANCE). No historical information about surface faulting is recorded in the archives and the fault source of this earthquake is still debated.

Previous investigations have supported the hypotheses that the 1356 historical earthquake might be due either to the activity of west-trending buried faults (e.g. Meyer et al., 1994), or to a north-trending Rhenish structure (e.g. Meghraoui et al., 2001). Nivière et al. (2008) investigated the north-south Rhenish structures (e.g. Rhine River fault; see Fig. 5) and concluded from morphological and borehole data that these structures are potentially able to generate earthquakes as large as $M=6.6-6.8$ in the magnitude range of the 1356 Basel earthquake, in a time frame of several tens of thousands of years.

Because of their proximity to the French nuclear power plant (NPP) of Fessenheim $(<10 \mathrm{~km})$, these potential active faults might pose a hazard to its safety. In order to perform an exercise aimed at assessing the fault parameters that influence most the results of PSHA calculations at short distance from a site (developed in Chartier et al., 2017), we propose as a first step to construct a fault source model based on the BDFA,

The three closest-to-NPP faults mapped in BDFA are the West Rhenish, the Rhine River and the Black Forest faults (faille Rhénane Ouest, faille du Rhin and faille de la Forêt Noire in BDFA respectively). Only the closest segments to the NPP are considered here (Fig. 5) and used in the PSHA exercises (see Chartier et al., 2017). Our knowledge of the considered fault segments activity is summarized by robustness indexes varying from $\mathrm{RI}=4.4$ up to $\mathrm{RI}=15.4$ (Fig. 5). Variation is mostly dependent on the presence or absence of spatially captured seismicity. However, for the purpose of the PSHA exercise performed in the parent paper, the reliability index has not been considered to weigh the activity of the fault segments. In addition, we assume that the static geologic discontinuities used to define the considered fault segments correspond to earthquake segment boundaries. In other words, we did not consider the possibility of multiple segment rupture scenarios in the PSHA exercise, which must be tested in future calculations. The table in Fig. 5c summarizes how the BDFA parameters were considered for PSHA calculations:

- Faults lengths: BDFA surficial traces are taken into account and digitized in PSHA CRISIS 2014 (Ordaz et al., 2014, Fig. 5). Lengths may slightly differ due to a rough digitization in the PSHA software. In BDFA, surficial fault traces (Fig. 5c) of the three considered faults were directly derived from the literature.

- Faults depths: in BDFA, we gave priority to fault depths characterized through geophysical prospections. Concerning the West Rhenish fault, for example, segment depths in BDFA are derived from the interpretation of reprocessed high-resolution industrial seismic profiles published by Rotstein and Schaming (2008). For the PSHA fault source model, we retain depths derived from the analysis of regional seismicity (Edel et al., 2006) and the interpretation of a crustal-scale seismic profile (DEKORP-ECORS, Brun and Wenzel, 1991). Two depth values will be tested for PSHA calculations: 15 and $20 \mathrm{~km}$.

- Faults dips: we mainly relied on the BDFA values, except for the Black Forest fault for which a higher angle equal to the Rhine River fault was preferred $\left(70 \pm 10^{\circ}\right)$, in line with what is proposed in Nivière et al. (2008). The hypothesis that these faults are structurally related, as proposed by Behrmann et al. (2003) and Rotstein et al. (2005) from reprocessed seismic data, should be tested in future studies. 


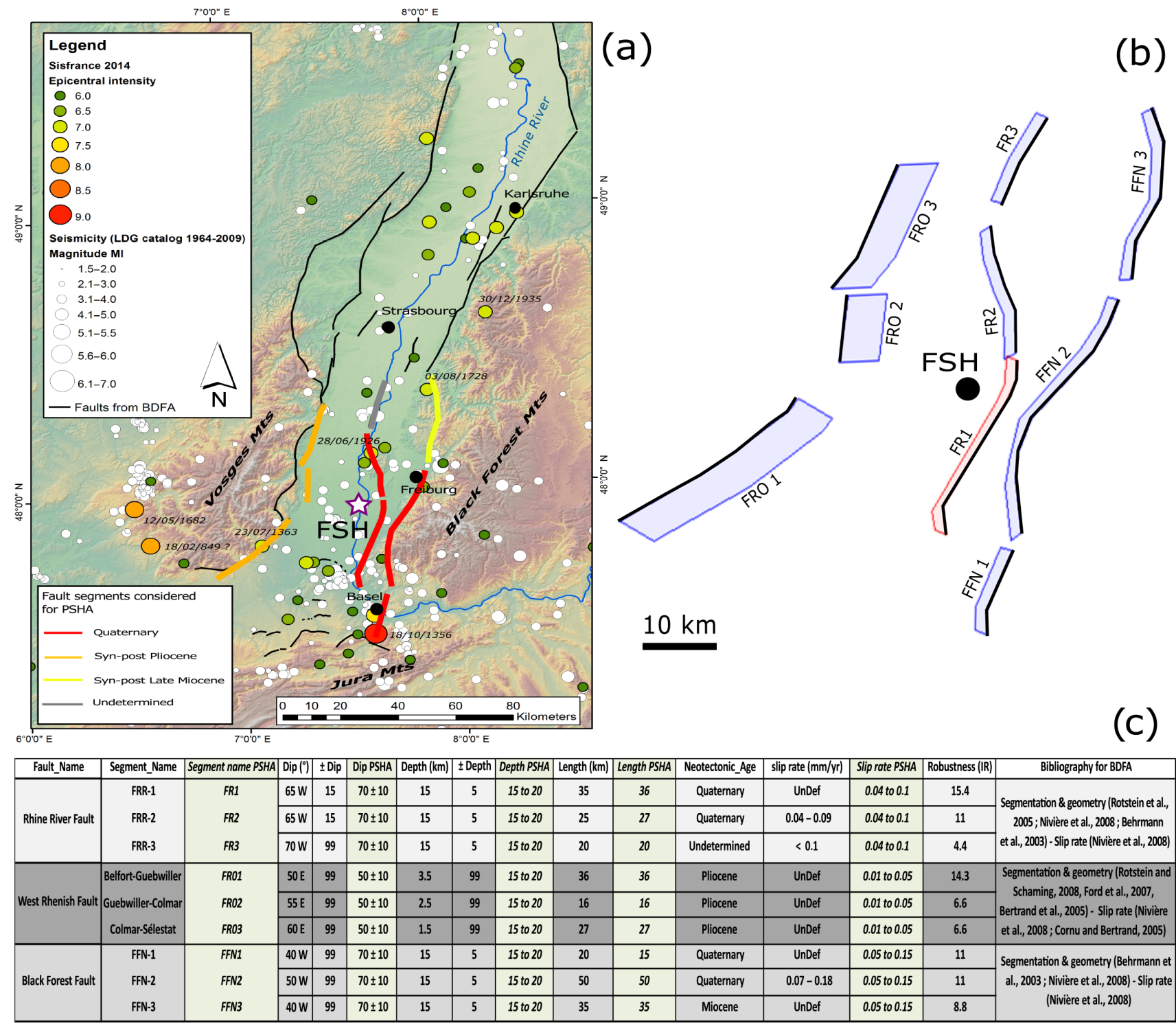

Figure 5. (a) Potentially active faults from BDFA (in black), selected segments for PSHA calculation in colour (depending on the age of the last movement on the fault). (b) Fault source model as produced for PSHA and extracted from CRISIS2014. Black lines correspond to the surficial trace of the fault segments, in light blue is the projection of fault planes at the surface (taking into account a $15 \mathrm{~km}$ depth and the maximum dip angle), in light red is the closest fault to FSH (Fessenheim NPP). (c) Table containing the principal parameters from BDFA (grey columns) and their transposition into the parametric PSHA fault source model (light green columns). Unknown data are reported Undef or 99 in the BDFA table.

- Faults slip rates: we considered slip rates contained in the BDFA (lower and upper bounds). For the Rhine River and the Black Forest faults, slip rates are available in the literature for only one segment of each fault; we then attributed coherent values to all segments for which no value were proposed in the literature. Slip rates along these fault segments were deduced from the analysis of post-Pliocene geological markers (Nivière et al., 2008). For the West Rhenish Fault, considered in BDFA as active during the Pliocene and possibly during the Quaternary, no slip rates were found in the literature. To this model we then attribute an upper bound of slip rate equal to the lower slip rate determined for both the Rhine River and Black Forest faults and a lower bound of slip rate coherent with lower fault-slip rates determined in the Lower Rhine Graben following Vanneste et al. (2013).

It is important to mention that in this part of the Rhine Graben, all fault slip rates that are available in the literature 
are given as vertical slip rates, considering that the long-term normal activity observed along these faults is representative of the ongoing deformation processes. However, data from seismicity (Edel et al., 2006), geodesy (Tesauro et al., 2005) as well as long-term regional stresses (Rotstein and Schaming, 2011) suggest a possible strike-slip component along faults in the Fessenheim area. To date, field data along faults are missing to confirm and quantify this strike-slip component (possibly dominant), but it is clear that such a hypothesis should be explored in future hazard assessments.

This exercise of converting the database into a fault source model shows that this transcription is not straightforward. Concerning the area we considered for this exercise, which is among the most studied in France, only five segments over nine present robustness indexes over 10, which means that the basic data we need to build a fault source model are either missing or of very poor quality. In this light, even if BDFA has been designed to integrate parameters required to implement a fault source model for PSHA, it is still necessary to make assumptions and account for alternatives when it comes to filling the model parameters.

\section{Discussion and perspectives}

In areas covered by the BDFA, the database represents the most complete source of information available in the literature to date. It is, however, clear that (1) the database needs to be extended to the entire country (metropolitan as well as neighbouring regions) for wider use than seismic hazards related to nuclear facilities, and (2) there is a need for future and periodic updating, especially in some areas such as the Alps and peripheral zones or the Rhine Graben.

However, for the time being, we are aware that the data contained in the database are mostly of low resolution as expressed through the robustness index. In metropolitan France, the main reasons for this situation are the following:

- Dating: because surficial deposits were strongly subjected to human reworking and erosion (mostly linked to glaciations), few markers are available to characterize the recent activity of faults (age, slip rates, etc.). In parallel, few Quaternary formations have been the subject of absolute dating campaigns and the age of deformations is often questionable. In this light, projects aiming at developing methodologies (such as the Proyecto Dataciòn performed in Spain, Santanach et al., 2001; Shyu et al., 2016 in Taïwan) would help to reduce dating uncertainties.

- Palaeoseismic evidence and seismic activity occur due to the very long recurrence periods of surface rupturing earthquakes. Because tectonic deformation rates are of the order of or even lower than erosion rates, very little palaeoseismic evidence has been identified so far in France. Then, the best way we currently have to es- timate the activity of faults is to be able to associate them to earthquakes, either instrumental or historical ones. Yet, apart from some temporary local seismic networks (Courboulex et al., 2003; Cushing et al., 2008), we are rarely able to associate the registered seismicity to a specific structure. It is then understandable that such time-consuming/costly studies are not sufficiently profitable for researchers in a context of scientific competition. In parallel, new ideas regarding the seismic behavior of stable continental regions (Calais et al., 2016) are sprouting, with the idea that the classical seismic cycle on a fault may not be the most plausible hypothesis and that the seismic potential could be more distributed in space and time. Then, questions arise related to the definition of what a stable continental region is and how to differentiate faults that could have the potential to produce major earthquakes from faults that could not. These questions are of growing importance. In any case, there is a crucial need to fund data gathering in metropolitan France, but also in regions with comparable geodynamical contexts in order to properly address and complement future seismic hazard analysis based on faults.

- Hidden and blind faults: some faults and fault segments without outcropping signatures have been recognized (such as the Belledone fault, Thouvenot et al., 2003) and are integrated into the database. However, studies conducted to highlight them are few in number. In this respect, studies leading to the reprocessing of industrial seismic profiles are likely to complete our knowledge, as well as studies devoted to relocate instrumental seismicity (Thouvenot et al., 2003; Courboulex et al., 2003).

The BDFA project, although it represents the state of the art of published studies, is inherently incomplete. It aims to be useful for identifying and planning the scientific campaigns that will be necessary for site-specific seismic hazard assessment studies. In this paper we propose a PSHA fault source model based on the transposition of BDFA data in order to conduct an exercise in the Upper Rhine Graben (developed in the parent paper - Part 2), aiming to quantify the relative influence of fault parameters on the hazard at a specific site. We underline here that industrial seismic data reprocessed from the GEORG project (http://www.geopotenziale. org/) show a more complex tectonic pattern in comparison to BDFA, illustrating the need to take into account structures that are not visible at the surface and should be taken into account in future hazard analyses. The reason that this data set was not included in the BDFA is that additional work, beyond the scope of this study, needs to be done to convert the GEORG structural scheme into BDFA parameters.

We also point out that according to international safety guides (IAEA, 2010), the fault displacement hazard, related to a fault that has a significant potential for displacement at or near the ground surface, should be explored for facilities 
located in the vicinity of potentially active faults. This hazard analysis (FDHA), however, requires a detailed and local data set as well, that BDFA clearly does not fulfil, but which again represents a guide for future investigations in metropolitan France.

Finally, the ongoing post-2011 Tohoku earthquake discussions have led to extreme events being envisaged as scenarios against which nuclear power plants need to be prepared. One possible way to foresee these events for SHA purposes may be to evaluate the maximum magnitude derived from the sizes of potential earthquake sources (i.e. the active faults). In that sense, the presented database may be useful but additional discussions on criteria to define fault segmentation and consecutively the potential for multi-segment ruptures is needed, as recalled recently by the Kaikoura earthquake in New Zealand that ruptured a very high number of fault segments (Hamling et al., 2017).

\section{Conclusion}

In this paper, we present a first release of a database of potentially active faults (BDFA) that defines and characterizes faults in their current state of knowledge. Such a database may be used during the elaboration of fault-based models for future seismic hazard analysis (SHA), either deterministic or probabilistic. In this light, BDFA was designed to include appropriate seismotectonic parameters (geometry, segmentation, slip rate, etc.).

This first release of the BDFA results from a 4-year endeavour in defining and compiling the database. Besides problems related to the completeness of some fields and the complete translation of the database in English (in progress), homogenizing the database is our first objective for the next release. This last point is largely explained by strong regional heterogeneities in data availability. In parallel, a website is currently under construction and will help us to gather more users' feedback to improve the database.

As a matter of fact, BDFA must not be considered to be a complete database and therefore cannot be a substitute for the necessary in-depth studies required to evaluate the hazard at a specific site.

Data availability. Data contained in BDFA are provided in the Supplement of this paper.

\section{The Supplement related to this article is available online at https://doi.org/10.5194/nhess-17-1573-2017- supplement.}

Competing interests. The authors declare that they have no conflict of interest.
Special issue statement. This article is part of the special issue "Linking faults to seismic hazard assessment in Europe". It is not associated with a conference.

Acknowledgements. The development of BDFA was funded by both the IRSN and the French ministry of environment. We first thank Hiromi Kobayashi and Vincent Courtray for their support to this project at the French Ministry for Environment. We would like to thank all persons that helped us to design and increment the database, and especially all the specialists who have agreed to review the forms associated to major faults of the database. We thank Oona Scotti for her fruitful comments, enthusiasm and help in writing and revising this paper. We finally sincerely thank Julian GarciaMayordomo and an anonymous referee for their careful review of our paper as well as Kuo Fong Ma for their constructive comments.

Despite all the care we have taken in the development of this database, it is possible that some errors remain here and there. We then would like to thank in advance all the persons that will contact us in order to share their experience and favour the development and quality of the database.

Edited by: Francesco Visini

Reviewed by: Julian Garcia-Mayordomo and one anonymous referee

\section{References}

AIST, National Institute of Advanced Industrial Science and Technology: Active Fault Database of Japan, April 4, 2016 version, Research Information Database DB095, National Institute of Advanced Industrial Science and Technology, Japan, available at: https://gbank.gsj.jp/activefault/index_e_gmap.html (last access: June 2017), 2016.

ASN: Basic safety rule 2001-01 of 31 may 2001, French Nuclear Safety Authority (ASN), Paris, France, available at: http://www.french-nuclear-safety.fr/References/Safety-Rules/ Basic-safety-rule-2001-01-of-31-may-2001 (last access: June 2017), 2001.

Baize, S., Cushing, E. M., Lemeille, F., Granier, T., Grellet, B., Carbon, D., Combes, P., and Hibsch, C.: Inventaire des indices de rupture affectant le Quaternaire en relation avec les grandes structures connues, en France métropolitaine et dans les régions limitrophes, Société géologique de France, Mémoire no. 175, 142 pp., 2002.

Baize, S., Cushing, M., Lemeille, F., Gélis, C., Texier, D., Nicoud, G., and Schwenninger, J. L.: Contribution to the seismic hazard assessment of a slow active fault, the Vuache fault in the southern Molasse basin (France), B. Soc. Geol. Fr., 182, 347365, https://doi.org/10.2113/gssgfbull.182.4.347, 2011.

Baize, S., Cushing, E. M., Lemeille, F., and Jomard, H.: Updated seismotectonic zoning scheme of Metropolitan France, with reference to geologic and seismotectonic data, B. Soc. Geol. Fr., 184, 225-259, 2013.

Barth, A., Ritter, J. R. R., and Wenzel, F.: Spatial variations of earthquake occurrence and coseismic deformation in the Upper Rhine Graben, Central Europe, Tectonophysics, 651, 172-185, 2015. 
Baumont, D., and Scotti, O.: The French Parametric Earthquake Catalogue (FPEC) based on the best events of the SisFrance macroseismic database-version 1.1, IRSN/DEI/2011-012, 2011.

Behrmann, J. H., Hermann, O., Horstmann, M., Tanner, D. C., and Bertrand, G.: Anatomy and kinematics of oblique continental rifting revealed: A three-dimensional case study of the southeast Upper Rhine Graben (Germany), Am. Assoc. Petr. Geol. B., 87, 1105-1121, 2003.

Bertrand, G., Horstmann, M., Hermann, O., and Behrmann, J. H.: Retrodeformation of the southern Upper Rhine Graben: new insights on continental oblique rifting, Quaternary Sci. Rev., 24, 345-352, 2005.

Biasi, G. P. and Wesnousky, S. G.: Steps and Gaps in Ground Ruptures: Empirical Bounds on Rupture Propagation, B. Seismol. Soc. Am., 106, 1110-1124, 2016.

Bonjer, K. P., Gelbke, C., Gilg, B., Rouland, D., Mayerrosa, D., and Massinon, B.: Seismicity and dynamics of the Upper Rhinegraben, J. Geophys.-Z. Geophys., 55, 1-12, 1984.

Bonnet, J., Fradet, T., Traversa, P., Tuleau-Malot, C., ReynaudBouret, P., Laloe, T., and Manchuel, K.: Completeness period analysis of SisFrance macroseismic database and interpretation in the light of historical context, EGU General Assembly, Vienna, Austria, 27 April-2 May 2014, EGU2014-12118, 2014.

Brun, J. P. and Wenzel, F.: Crustal scale structure of the southern Rhinegraben from ECORS/DEKORP seismic reflection data, Geology, 19, 758-762, 1991

Calais, E., Camelbeeck, T., Stein, S., Liu, M., and Craig, T. J.: A new paradigm for large earthquakes in stable continental plate interiors, Geophys. Res. Lett., 43, 10621-10637, https://doi.org/10.1002/2016GL070815, 2016.

Chardon, D., Hermitte, D., Nguyen, F., and Bellier, O.: First paleoseismological constraints on the strongest earthquake in France (Provence) in the twentieth century, Geology, 33, 901-904, 2005.

Chartier, T., Scotti, O., Clément, C., Jomard, H., and Baize, S.: Transposing an active fault database into a fault-based seismic hazard assessment for nuclear facilities - Part 2: Impact of fault parameter uncertainties on a site-specific PSHA exercise in the Upper Rhine Graben, eastern France, Nat. Hazards Earth Syst. Sci., 17, 1585-1593, https://doi.org/10.5194/nhess17-1585-2017, 2017.

Cornu, T. and Bertrand, G.: Numerical backward and forward modeling of the southern Upper Rhine Graben (France-Germany border): new insights on tectonic evolution of intracontinental rifts, Quaternary Sci. Rev., 24, 353-361, 2005.

Courboulex, F., Larroque, C., Deschamps, A., Gélis, C., Charreau, J., and Stéphan, J. F.: An unknown active fault revealed by microseismicity in the south-east of France, Geophys. Res. Lett., 30, 1782, https://doi.org/10.1029/2003GL017171, 2003.

Cushing, E. M., Bellier, O., Nechtschein, S., Sébrier, M., Lomax, A., Volant, Ph., Dervin, P., Guignard, P., and Bove, L.: A multidisciplinary study of a slow-slipping fault for seismic hazard assessment: the example of the Middle Durance Fault (SE France), Geophys. J. Int., 172, 1163-1178, 2008.

De La Taille, C., Jouanne, F., Crouzet, C., Beck, C., Jomard, H., De Rycker, K., and Van Daele, M.: Impact of active faulting on the post LGM infill of Le Bourget Lake (western Alps, France), Tectonophysics, 664, 31-49, 2015.
Edel, J. B., Whitechurch, H., and Diraison M.: Seismicity wedge beneath the Upper Rhine Graben due to backwards Alpine push?, Tectonophysics, 428, 49-64, 2006.

Field, E. H., Biasi, G. P., Bird, P., Dawson, T. E., Felzer, K. R., Jackson, D. D., Johnson, K. M., Jordan, T. H., Madden, C., Michael, A. J., Milner, K. R., Page, M. T., Parsons, T., Powers, P. M., Shaw, B. E., Thatcher, W. R., Weldon II, R. J., and Zen, Y.: Longterm time-dependent probabilities for the third Uniform California Earthquake Rupture Forecast (UCERF3), B. Seismol. Soc. Am., 105, 511-543, 2015.

Ford, M., Le Carlier de Veslud, C., and Bourgeois, O.: Kinematic and geometric analysis of fault-related folds in a rift setting: The Dannemarie basin, Upper Rhine Graben, France, J. Struct. Geol., 29, 1811-1830, 2007.

Fourniguet, J.: Notice de la carte néotectonique de la France à 1/1,000,000, BRGM/SGN/GEO report, 1978

García-Moreno, D., Verbeeck, K., Camelbeeck, T., De Batist, M., Oggioni, F., Hurtado, O. Z., Versteeg, W., Jomard, H., Collier, J. S., Gupta, S., and Trentesaux, A.: Fault activity in the epicentral area of the 1580 Dover Strait (Pas-de-Calais) earthquake (northwestern Europe), Geophys. J. Int., 201, 528-542, 2015.

García-Mayordomo, J., Insua-Arévalo, J. M., Martínez-Díaz, J. J., Jiménez-Díaz, A., Martín-Banda, R., Martín-Alfageme, S. Álvarez-Gómez, J. A., Rodríguez-Peces, M., Pérez-López, R., Rodríguez-Pascua, M. A., Masana, E., Perea, H., MartínGonzález, F., Giner-Robles, J., Nemser, E. S., Cabral, J., and QAFI Compilers: The Quaternary Active Faults Database of Iberia (QAFI v. 2.0)/La Base de Datos de Fallas Activas en el Cuaternario de Iberia (QAFI v. 2.0), J. Iber. Geol., 38, 285-302, 2012.

Grellet, B., Combes, P., Granier, T., and Philip, H.: Sismotectonique de la France métropolitaine dans son cadre géologique et géophysique, Société géologique de France, Mémoire no. 164, 1993.

Haller, K. M., Machette, M. N., Dart, R. L., and Rhea, B. S.: U.S. Quaternary fault and fold database released, Eos T. Am. Geophys. Un., 85, 218-218, https://doi.org/10.1029/2004EO220004, 2004.

Hamling, I. J., Hreinsdóttir, S., Clark, K., Elliott, J., Liang, C., Fielding, E., Litchfield, N., Villamor, P., Wallace, L., Wright, T. J., D’Anastasio, E., Bannister, S., Burbidge, D., Denys, P., Gentle, P., Howarth, J., Mueller, C., Palmer, N., Pearson, C., Power, W., Barnes, P., Barrell, D. J. A., Van Dissen, R., Langridge, R., Little, T., Nicol, A., Pettinga, J., Rowland, J., and Stirling, M. Complex multifault rupture during the $2016 M_{\mathrm{W}} 7.8$ Kaikōura earthquake, New Zealand, Science, 356, eaam7194, https://doi.org/10.1126/science.aam7194, 2017.

IAEA: Seismic hazards in site evaluation for nuclear installations, International Atomic Energy Agency (IAEA), Vienna, Specific Safety Guide, No. SSG-9, 56 pp., 2010.

Lambert, J., Winter, T., Dewez, T. J., and Sabourault, P.: New hypotheses on the maximum damage area of the 1356 Basel earthquake (Switzerland), Quaternary Sci. Rev., 24, 381-399, 2005.

Langridge, R. M., Ries, W. F., Litchfield, N. J., Villamor, P., Van Dissen, R. J., Barrell, D. J. A., Rattenbury, M. S., Heron, D. W., Haubrock, S., Townsend D. B., Lee, J. M., Berryman, K. R., Nicol, A., Cox, S. C., and Stirling, M. W.: The New Zealand Active Faults Database, New Zeal. J. Geol. Geop., 59, 86-96, 2016. 
Meghraoui, M., Delouis, B., Ferry, M., Giardini, D., Huggenberger, P., Spottke, I., and Granet, M.: Active Normal Faulting in the Upper Rhine Graben and Paleoseismic IdentiTcation of the 1356 Basel Earthquake, Science, 293, 2070-2073, 2001.

Meyer, B., Lacassin, R., Brulhet, J., and Mouroux, B.: The Basel 1356 earthquake: which fault produced it?, Terra Nova, 6, 5463, 1994.

Michetti, A. M., Serva, L., and Vittori, E.: ITHACA Italy Hazard from Capable Faults: a database of active faults of the Italian onshore territory, CD-Rom and explicative notes, ANPA, Italy, 2000.

NEOPAL: Base de données nationale des déformations récentes et des paléoséismes, available at: http://www.neopal.net (last access: June 2017), 2009.

Nivière, B., Bruestle, A., Bertrand, G., Carretier, S., Behrmann, J., and Gourry, J.-C.: Active tectonics of the southeastern Upper Rhine Graben, Freiburg area (Germany), Quaternary Sci. Rev., 27, 541-555, 2008.

Ordaz, M., Martinelli, F., Aguilar, A., Arboleda, J., Meletti, C., and D'Amico, V.: CRISIS 2014, Program for computing seismic hazard, Instituto de Ingeniería, Universidad Nacional Autónoma de México, Mexico, 2014.

Palumbo, L., Baize, S., Cushing, M., Jomard, H., and David, C.: Devising BDFA: a new active fault database conceived behind nuclear safety assessment in France, 4th International INQUA Meeting on Paleoseismology, Active Tectonics and Archeoseismology (PATA), 9-14 October 2013, Aachen, Germany, 181185, 2013.

Rotstein, Y. and Schaming, M.: Tectonic implications of faulting styles along a rift margin: The boundary between the Rhine Graben and the Vosges Mountains, Tectonics, 27, TC2001, https://doi.org/10.1029/2007TC002149, 2008.

Rotstein, Y. and Schaming, M.: The Upper Rhine Graben (URG) revisited: Miocene transtension and transpression account for the observed first-order structures, Tectonics, 30, TC3007, https://doi.org/10.1029/2010TC002767, 2011.

Rotstein, Y., Behrmann, J. H., Lutz, M., Wirsing, G., and Luz, A.: Tectonic implications of transpression and transtension: The Upper Rhine Graben, Tectonics, 24, TC6001, https://doi.org/10.1029/2005TC001797, 2005.
Santanach, P., Masana, E., and Villamarìn, J. A.: Proyecto dataciòn. Consejo de Seguridad Nuclear, Barcelona, 159 pp., 2001.

Sébrier, M., Ghafiri, A., and Bles, J.-L.: Paleoseismicity in France: Fault trench studies in a region of moderate seismicity, J. Geodyn., 24, 207-217, 1997.

Shyu, J. B. H., Chuang, Y. R., Chen, Y. L., Lee, Y. R., and Cheng, C. T.: A New On-Land Seismogenic Structure Source Database from the Taiwan Earthquake Model (TEM) Project for Seismic Hazard Analysis of Taiwan, Terrestrial, Atmospheric and Oceanic Sciences, 27, 311-323, 2016.

SISFRANCE: Base de données nationale de la sismicité historique de la France, BRGM, EDF, IRSN, available at: http://www. sisfrance.net, last access: June 2017.

Terrier, M.: Identification et Classification des failles actives de la Région Provence-Alpes-Côte d'Azur - Phase 2: Analyse et synthèse des connaissances actuelles sous la forme de fiches descriptives des failles, Rapport BRGM/RP-5315-FR, 342 pp., 2004.

Tesauro, M., Hollenstein, C., Egli, R., Geiger, A., and Kahle, H. G.: Continuous GPS and broad-scale deformation across the Rhine Graben and the Alps, Int. J. Earth Sci., 94, 525-537, 2005.

Thouvenot, F., Fréchet, J., Jenatton, L., and Gamond, J. F.: The Belledonne Border Fault: identification of an active seismic strike-slip fault in the western Alps, Geophys. J. Int., 155, 174192, 2003.

U.S. NRC: Appendix A to Part 100 - Seismic and Geologic Siting Criteria for Nuclear Power Plants, NRC Regulation (10 CFR), last update 2017.

Vanneste, K., Camelbeeck, T., and Verbeeck, K..: A model of composite seismic sources for the Lower Rhine Graben, Northwest Europe, B. Seismol. Soc. Am., 103, 984-1007, 2013.

Wells, D. L. and Coppersmith, K. J.: New empirical relationships among magnitude, rupture length, rupture width, rupture area, and surface displacement, B. Seismol. Soc. Am., 84, 974-1002, 1994.

Wesnousky, S. G.: Earthquakes, Quaternary faults, and seismic hazard in California, J. Geophys. Res., 91, 12587-12631, 1986. 